\title{
Usefulness of endoscopic ultrasonography (EUS) for selecting carcinoid tumors as candidates to endoscopic resection
}

\author{
M. J. Varas ${ }^{1}$, J. B. Gornals ${ }^{2}$, C. Pons ${ }^{3}$, J. C. Espinós ${ }^{1}$, R. Abad ${ }^{1}$, F. J. Lorente ${ }^{2}$ and D. Bargalló ${ }^{2}$ \\ Unidad de Ecoendoscopia. ${ }^{l}$ Centro Médico Teknon. ${ }^{2}$ Centro Médico Delfos. Barcelona. ${ }^{3}$ Unidad de Endoscopia. Servicio \\ de Aparato Digestivo. Hospital Universitario de Bellvitge. Hospitalet de Llobregat, Barcelona
}

\begin{abstract}
Introduction: carcinoid tumors (CTs) represent the most common type of neuroendocrine tumors (NETs). Digestive CTs in the gastroduodenal and colorectal tracts may be assessed using endoscopy and echoendoscopy or endoscopic ultrasonography (EUS) with the goal of attempting local resection with curative intent without having recourse to surgery.

Objective: endpoints in this study included:

-Assessing the usefulness of EUS for selecting CTs as candidates to endoscopic excision.

-Assessing the effectiveness of local resection (complete carcinoid resection) and the safety (complications) of the technique involved.
\end{abstract}

Patients and methods: our series included 18 patients (12 males and 6 females) with 23 tumors. Sixteen patients (10 males and 6 females) were selected, with age ranging from 40 to 81 years (mean: 57 years), biopsied, endoscopically treated digestive carcinoid tumors, and a previous negative extension study. Twenty-one 2-to-20-mm (mean size $8 \mathrm{~mm}$ ) tumors were resected in 23 procedures.

After endoscopy plus biopsy and echoendoscopy (EUS), excision was carried out with conventional polypectomy snare mucosectomy and submucosal injection with saline and/or adrenaline in most cases (15), and mucosectomy technique following lesion ligation with elastic bands for six cases. Two cases underwent transanal endoscopic surgery (TEM), one of them following noncurative polypectomy. A total of 23 local procedures were performed with the key goal of assessing efficacy (complete resection: $\mathrm{CR}$ ) and safety (complications).

Results: there were no severe complications except for the last gastric mucosectomy for a 6-mm carcinoid, where a miniperforation occurred that was solved by using 3 clips (1/23: 4.3\%). $(19 / 21)$

EUS sensitivity was 94\%. Complete resection was 90.5\%

\section{RESUMEN}

Introduccion: los tumores carcinoides (TC) son los tumores neuroendocrinos (TNEs) más frecuentes. Los TC digestivos localizados en el tracto gastroduodenal y rectocolónico pueden ser evaluados por endoscopia y por ecoendoscopia o ultrasonografía endoscópica (USE), con el objetivo de efectuar una resección local como tratamiento curativo sin recurrir a la cirugía.

Objetivo: los objetivos finales de este estudio fueron:

- Analizar si es útil la USE en la selección de TC como candidatos a una extirpación endoscópica.

- La evaluación de la eficacia de la resección local (resección completa del carcinoide) y la seguridad (complicaciones) de la técnica efectuada.

Pacientes y metodos: la serie consta de 18 pacientes (12 varones y 6 mujeres) con 23 tumores. Se han seleccionado 16 pacientes (10 varones y 6 mujeres) con un rango de 40 a 81 años (media: 57 años), con tumores carcinoides digestivos biopsiados y tratados endoscópicamente, con estudio previo de extensión negativo. Se resecaron 21 tumores de 2 a $20 \mathrm{~mm}$ (tamaño medio: $8 \mathrm{~mm}$ ), en 23 procedimientos.

Después de endoscopia más biopsia y ecoendoscopia (USE), se llevó a cabo la extirpación mediante mucosectomía con asa de polipectomía convencional e inyección submucosa con suero salino y/o adrenalina en la mayoría de casos (15) y en seis con técnica de mucosectomía tras ligar la lesión con bandas elásticas. En dos casos con cirugía endoscópica transanal (TEM) (uno después de haber efectuado polipectomía no curativa). Se efectuaron en total 23 tratamientos localizados con el objetivo fundamental de evaluar la eficacia (resección completa: RC) y seguridad (complicaciones).

Resultados: no hubo complicaciones muy importantes, excepto en la última mucosectomía gástrica por un carcinoide de 6 $\mathrm{mm}$, en la que se produjo una miniperforación (1/23: 4,3\%) que se resolvió con la colocación de 3 clips.

La sensibilidad de la USE fue del 94\%. La resección completa fue del 90,5\% (19/21).

Received: 02-02-10.

Accepted: 10-03-10. 
Conclusions: the endoscopic mucosal resection of selected carcinoid tumors is a safe, effective technique. EUS is the technique of choice to select patients eligible for endoscopic resection (carcinoids smaller than $20 \mathrm{~mm}$ in superficial layers, with an unscathed muscularis propria and negative extension study).

Key words: Digestive carcinoid tumors. Gastroduodenal and colorectal carcinoid tumors. Endoscopic ultrasonography. Endoscopic mucosal resection. Polypectomy. Mucosectomy. With bands. Transanal endoscopic microsurgery. Complications.
Conclusiones: la resección mucosa endoscópica de tumores carcinoides seleccionados es una técnica segura y eficaz. La USE es la técnica de elección para seleccionar los pacientes candidatos a resección endoscópica (carcinoides menores de $20 \mathrm{~mm}$ situados en las primeras capas, con muscular propia indemne y con estudio de extensión negativo).

Palabras clave: Tumores carcinoides digestivos. Tumores carcinoides gastroduodenales y rectocolónicos. Ultrasonografía endoscópica. Resección mucosa endoscópica. Polipectomía, mucosectomía. Con bandas. Microcirugía endoscópica transanal.

Varas MJ, Gornals JB, Pons C, Espinós JC, Abad R, Lorente FJ, Bargalló D. Usefulness of endoscopic ultrasonography (EUS) for selecting carcinoid tumors as candidates to endoscopic resection. Rev Esp Enferm Dig 2010; 102: 577-582.

\section{INTRODUCCIÓN}

Carcinoid tumors (CTs) are the most common neuroendocrine tumors (NETs) with an incidence of 1 case $/ 100,000$ people/year (1), and are on the rise in the last few years.

Pulmonary CTs represent around $2 \%$ of all primary lung tumors and fewer than $25 \%$ of all CTs; the rest are digestive lesions $(74 \%)(2,3)$.

Gastric CTs (GCTs) may be associated with type-A chronic atrophic gastritis or pernicious anemia (GCT type 1 , up to $75 \%, 50 \%$ multifocal), Zollinger-Ellison syndrome (ZES), and multiple endocrine neoplasm (MEN-1) (GCT type 2, 5-10\% of cases), or may be sporadic (GCT type $3,15-25 \%)$, many of them single and metastatic lesions (3).

Digestive CTs in the gastroduodenal (5\%) and colorectal (10 and 11\%) tract may be assessed with endoscopy (2) and with echoendoscopy or endoscopic ultrasonography (EUS) with the goal of performing an endoscopic mucosal resection as curative therapy instead of surgery for local disease.

Gastroduodenal and rectal carcinoids smaller than 1 $\mathrm{cm}$ develop metastatic disease in fewer than $2 \%$ of cases $(4,5)$; thus, when EUS reveals an unscathed muscularis propria local treatment can be effectively and safely performed.

When CT size is $1-2 \mathrm{~cm}$ therapy selection may be controversial since $10-15 \%$ (5) are estimated to develop metastasis, hence the treatment of choice will depend on patient age and surgical risk.

Tumors greater than $2 \mathrm{~cm}$ will develop metastatic disease in $60-80 \%$ of cases $(4,5)$, with rectal lesions infiltrating the muscularis propria in $88 \%$ of cases, which demands radical surgery.

\section{OBJECTIVE}

Study endpoints included:

- Analyzing whether EUS is useful for screening CTs eligible for endoscopic excision.

-An assessment of local resection effectiveness (complete resection) and technique safety (complications).

\section{PATIENTS AND METHODS}

Our series includes 18 patients (12 males, 6 females) with 23 tumors identified from January 1st, 1997 to January 1st, 2009. Two patients with tiny tumors smaller than $5 \mathrm{~mm}$ in the rectum were excised, and biopsy samples were obtained.

Sixteen patients were selected (10 males and 6 females) with age ranging from 40 to 81 years (mean: 57 years) with digestive CTs biopsied and endoscopically treated from 1997 to 2009 , and with a previous negative extension study; they were seen at Centro Médico Teknon, Barcelona, Hospital Universitario de Bellvitge, Hospitalet de Llobregat, and Centro Médico Delfos, Barcelona. This was a retrospective study.

Six physicians ( 2 per site) cooperated in therapies performed.

Twenty-one 2-20-mm tumors were resected (mean size: $8 \mathrm{~mm}$ ).

Inclusion criteria for local therapy included patients with submucosal tumors smaller than $1 \mathrm{~cm}$ where EUS showed an unscathed muscularis propria, absence of perilesional adenopathies, and an extension study ruling out distant metastases. 
Patients with tumors $1-2 \mathrm{~cm}$ in size and high surgical risk were also included.

Exclusion criteria included: size greater than $2 \mathrm{~cm}$, muscularis propria infiltration, presence of perilesional adenopathies, and/or presence of distant metastases.

All patients with an identified digestive submucosal lesion and/or biopsy consistent with CT underwent EUS with a conventional radial or sectorial 7.5 -to- $20-\mathrm{MHz}$ echoendoscope or 12-15-20-MHz miniprobe.

Parameters primarily assessed included size, EUS pattern and lesion depth, involved layers, and the presence of perilesional adenopathies.

All explorations were performed with an informed consent and under sedation (propofol) by an anesthetist.

Resection was performed using a conventional polypectomy loop, mucosectomy assisted by saline and/or diluted adrenaline submucosal injection, or mucosectomy aided by elastic band placement (6 cases).

Two anorectal carcinoids underwent transanal endoscopic microsurgery (TEM).

The pathology study included immunohistochemistry for chromogranin and synaptophysin in most cases, and Ki 67 in 4 cases.

Follow-up consisted of endoscopic crust biopsies at months 1,6 and 12 following resection.

\section{RESULTS}

EUS failed to detect a tiny lesion, a false negative (F-) result, and there was a false positive $(\mathrm{F}+)$ finding; hence sensitivity was $94 \%$.

Twenty-one carcinoid tumors in 16 patients with a mean age of 57 years (range 40-81 years) were treated. Ten were found in males $(62.5 \%)$ and six in women $(37.5 \%)$.

Demographic characteristics are listed in table I.

Bleeding rate was $0 \%$ whereas perforation rate was $4.3 \%$ (gastric miniperforation solved by 3 clips and observational follow-up for 72 hours).

Complete resection (CR) was $90.5 \%$ (19/21) with a minimum follow-up of 12 months.

In cases undergoing conventional polypectomy $\mathrm{CR}$ was $86.7 \%(13 / 15)$ versus $100 \%$ (8/8) with band-aided mucosectomy or TEM.

\section{DISCUSSION}

Endoscopic resection for carcinoid tumors has been performed for ten years now, particularly by Japanese authors (6). Imada-Shirakata (7) and Higaki et al (8) demonstrated that rectal carcinoid tumors smaller than 10 $\mathrm{mm}$ and with extension within the submucosal layer (intact muscularis propria) have a minimal risk for metastatic disease.
Table I

\begin{tabular}{lc}
\hline Variables & Number of patients (\%) \\
\hline Patients & 16 \\
Gender: & $10(62.5 \%)$ \\
Males & $6(37.5 \%)$ \\
Females & 21 \\
Resected CTs & 23 \\
Procedures & $7(43 \%)$ \\
Patients with multifocal CTs & \\
Associated conditions & 2 \\
Atrophic gastritis. type A & 2 \\
MEN-1 & \\
Location: & $13(62 \%)$ \\
Stomach & $4(19 \%)$ \\
Duodenum & $4(19 \%)$ \\
Rectum & \\
Size & \\
Smaller than 10 mm & $17(80.9 \%)$ \\
10-20 mm & $3(14 \%)$ \\
More than 20 mm & $1(4.7 \%)$ \\
Resection technique & \\
Conventional snare-assisted polypectomy with subm. inj & $15(65 \%)$ \\
Band-assisted mucosectomy & $6(26 \%)$ \\
Transanal endoscopic microsurgery (TEM) & $2(8.7 \%)$ \\
Complete resection & $19 / 21(90.5 \%)$ \\
Complications & \\
Mini-perforation & $1(4.3 \%)$ \\
Bleeding & $0(0 \%)$ \\
\hline &
\end{tabular}

Yohikane (9) treated 7 cases of duodenal (bulbar) carcinoid tumors 1.5 to $7 \mathrm{~mm}$ (X: $4.3 \mathrm{~mm}$ ) in size with a complete resection rate of $100 \%$. See Table 2. There was a good correlation between size as estimated by EUS and resected piece (9) (13).

Kobayashi (15) studied 66 rectal carcinoids -- 57 were smaller than $10 \mathrm{~mm}$, and $9(14 \%)$ were greater than 11 $\mathrm{mm}$; the latter subgroup showed muscularis propria infiltration in 5 cases and metastatic disease in 4 cases. In our series we found no muscularis propria infiltration or distant metastases for tumors measuring 1-2 cm (14\%); in one case where EUS showed submucosal involvement and muscularis propria compression (Figs. 1 and 2), TEM was performed following polypectomy because of uncertainty regarding the resected piece (deep infiltration), and no persistent carcinoid was found following TEM.

Various techniques have been described: a) conventional technique with polypectomy loop, b) technique aided by submucosal injection with various substances, c) lesion aspiration within a cap, d) lesion rising using elastic band ligation, double-band ligation, mixed techniques, etc.

Kajiyama et al (6) state that using an aspiration method, whether a cap or band ligation, is more effective 
Table II. Literature review

\begin{tabular}{|c|c|c|c|c|c|}
\hline Author and year & No. cases & Perforation & Bleeding & $C R$ & Follow-up \\
\hline Kajiyama 1996 & $\begin{array}{l}\text { Cap or band aspiration } \\
\text { Polypectomy }(\mathrm{P})\end{array}$ & & & $\begin{array}{l}87 \% \\
74 \%\end{array}$ & \\
\hline Yohikane 1998 & $\begin{array}{l}7 \text { c. Bulb } \\
X: 4.3 \mathrm{~mm}(1.5-7 \mathrm{~mm})(P)\end{array}$ & $1 / 7(14 \%)$ & $0(0 \%)$ & $100 \%$ & $6-46 m$ \\
\hline Ichikawa 2003 & 5 gastric $C .(P)$ & & & $100 \%$ & $6-66(32 m)$ \\
\hline Ono 2003 & $\begin{array}{l}14 \text { bands } \\
14 \text { polyp. }\end{array}$ & & & $\begin{array}{l}100 \% \\
58 \%\end{array}$ & $10.5 \mathrm{~m}$ \\
\hline Varas 2003 & $9 \mathrm{P}$ and 1 band & $(0 \%)$ & $0(0 \%)$ & $100 \%$ & \\
\hline Martínez 2004 & $\begin{array}{l}22 \mathrm{P} \text { and } 2 \text { band } \\
21 \mathrm{c} \text {. with } 24 \text { tumors X: } 8.95 \mathrm{vs} .9 \mathrm{~mm}\end{array}$ & $(0 \%)$ & $1(4 \%)$ & $100 \%$ & $12 \mathrm{~m}$ \\
\hline Kobayashi 2005 & 66 c. rectal $(\mathrm{P})$ : & $\begin{array}{l}57 \text { smaller than } 10 \mathrm{~mm} \\
9 \text { greater than } 11 \mathrm{~mm} \\
5 \mathrm{MP} \text { infiltration and } 4 \mathrm{~m}\end{array}$ & & $83 \%$ & \\
\hline Sakata 2006 & $\begin{array}{l}8 \text { bands } \\
7 \text { polyp. }\end{array}$ & $(0 \%)$ & & $\begin{array}{l}100 \% \\
57 \%\end{array}$ & $36 m$ \\
\hline Moon 2006 & 11 double band & $(0 \%)$ & $0(0 \%)$ & $100 \%$ & \\
\hline Zhou 2007 & $25 \mathrm{R}(3-15 \mathrm{~mm})(\mathrm{B})(0 \%)$ & $0(0 \%)$ & & $100 \%$ & $18 \mathrm{~m}$ \\
\hline Kim 2008 & 30 c. R (X: 6.29 mm) (Cap.) & & & $70 \%$ & $19 \mathrm{~m}$ \\
\hline Sohn 2008 & 41 c. with 42 R Cap (0\%) & $0(0 \%)$ & & $85.7 \%$ & \\
\hline Mashimo 2008 & $63 \mathrm{R}$ with bands & $(0 \%)$ & $5(7.9 \%)$ & $95 \%$ & $0 \% 24 \mathrm{~m}$ \\
\hline Abe 2008 & $\begin{array}{l}20 \mathrm{R} \text { with bands } \\
\text { 3D-EUS }\end{array}$ & $(0 \%)$ & $0(0 \%)$ & $100 \%$ & \\
\hline Yamaguchi 2010 & $\begin{array}{l}20 \text { rectal } \\
\text { ESD. X: } 7.6 \mathrm{~mm}(3-16 \mathrm{~mm})\end{array}$ & $1 / 20(5 \%)$ & $0(0 \%)$ & $90 \%$ & $4-34 m$ \\
\hline Onozato 2010 & $40 \mathrm{R}<1 \mathrm{~cm}$ & $(0 \%)$ & 0 & $85 \%$ EMR vs. $78 \%$ ESD & $76.8 \mathrm{~m}$ \\
\hline Varas 2010 & $\begin{array}{l}21(4 \mathrm{R})(6 \mathrm{~B}) 1 / 23(4.3 \%) \\
\text { Various techniques: } 16 \mathrm{c} \text {. with } 21 \mathrm{X} \text { tumors: } \\
\text { Polypectomy } \\
\text { Bands and TEM }\end{array}$ & $\begin{array}{l}0(0 \%) \\
8 \mathrm{~mm}(2-20 \mathrm{~mm})\end{array}$ & & $\begin{array}{l}90.5 \% \\
86.7 \% \\
100 \%\end{array}$ & $12.0 \mathrm{~m}$ \\
\hline Summary & $>400$ cases & $0-14 \%(2 \%)$ & $0-7.9 \%(1 \%)$ & $57-100 \%(88 \%)$ & $4-76 m$ \\
\hline
\end{tabular}

CR: complete resection. ESD: endoscopic submucosal dissection.

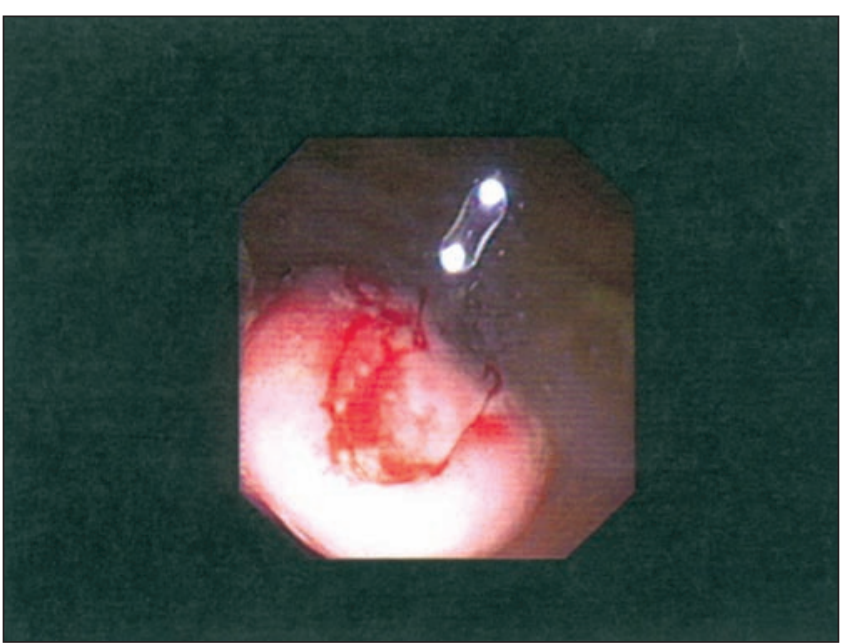

Fig. 1. Polypectomy for rectal carcinoid.

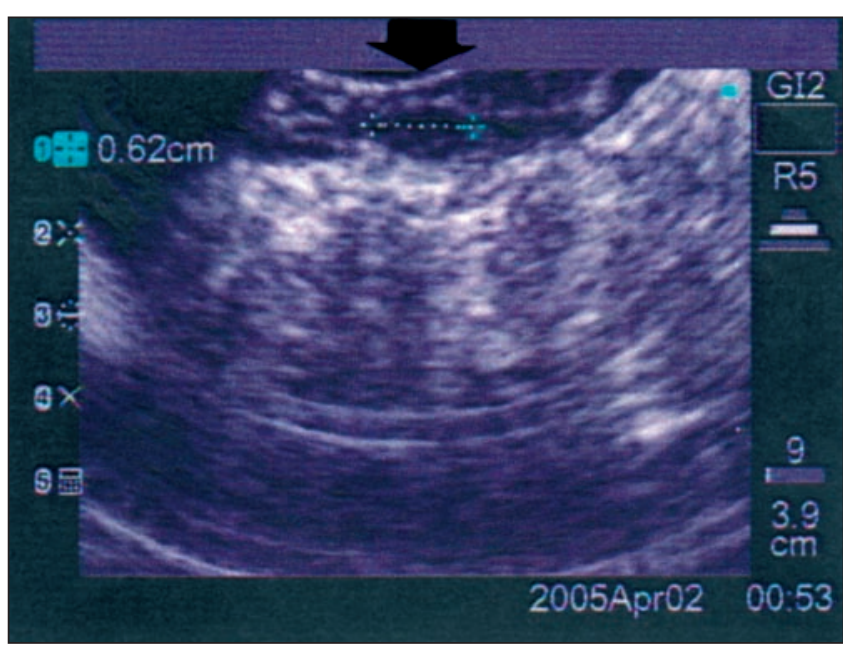

Fig. 2. Sectorial 7.5-MHz EUS for a 6.2-mm rectal carcinoid. 
than assisted polypectomy (87\% vs. $74 \%)$.

Ono (11) and Sakamata (16) compared the conventional technique with elastic bands, showing vastly superior results with the latter (58-57 vs. 100\%). However, some author has suggested that double-band should be the technique of choice (17) for preventing perforation and bleeding $(0 \%)$, with a CR rate of $100 \%$.

These results differ from our experience in our country in that polypectomy led to good results in $100 \%$ of subjects (12) (13). On separating CTs into two groups according to treatment we obtained $86.7 \%$ versus $100 \%$, even with a limited sample size.

For Korean authors (18), bands lead to CR in $100 \%$ of cases, whereas conventional polypectomy has a $\mathrm{CR}$ rate of around $75 \%$. EUS had an accuracy and sensitivity of $100 \%$, similar to that obtained by us $(95 \%)$.

The latest results regarding band-managed rectal carcinoids provide a complete resection rate of $95 \%$ with no perforations and with hemoclip-controlled bleeding (21), and of $90 \%$ when endoscopic submucosal dissection (ESD) was used (23). This same figure was obtained in this study for gastroduodenales and rectal carcinoids where several treatment techniques were used.

Two of our cases underwent transanal endoscopic microsurgery (TEM) with good results, as already indicated by the literature on rectal carcinoid management (25).

Our approach to small (smaller than $2 \mathrm{~cm}$ ) rectal carcinoids relies on EUS or previous endoanorectal ultrasounds; in the absence of muscularis propria infiltration an endoscopic resection rather than local surgical resection will be performed (26). TEM will be used for positive resection margins, and radical surgery is restricted to lesions greater than $2 \mathrm{~cm}$, as metastatic disease rates approach $83 \%$ and muscularis propria infiltration rates are $88 \%$ in such cases (27). Surgical rectal resection may also be recommended for tumors $1-1.9-\mathrm{cm}$ in size with high-risk changes such as muscularis propria infiltration, and lymphovascular or perineural involvement (28), albeit endoscopic treatment suffices for most cases (lesions smaller than $1 \mathrm{~cm}$ limited to the mucosa) (28) (29) (30).

Our way of approaching gastric carcinoid, types 1 and 2, when smaller than $5 \mathrm{~mm}$ is endoscopic control (31) (32); when equal to or greater than $10 \mathrm{~mm}$ with no muscularis propria infiltration, endoscopic resection (33). For type-3 gastric carcinoids smaller than $20 \mathrm{~mm}$ we also perform endoscopic resection, and keep surgery for lesions greater than $20 \mathrm{~mm}$ with muscularis propria infiltration or perilesional adenopathies.

Complication (bleeding, perforation) rates are usually small; bleeding is more common (0 to $7.7 \%$ ) (mean: $1 \%$ ) -- it may be self-limited at times or can be endoscopically managed, particularly for gastric carcinoids (13) (Tables 2 and 3 ).

EUS may be useful for detecting blood vessels neighboring the carcinoid (13), and for diagnosis, with an accuracy and sensitivity of $100 \%$ (18), 94\% for us, and $71 \%$ precision is a recent study of 20 gastroduodenal carcinoids (34), most of them homogeneous, hypoechogenic lesions smaller than $1 \mathrm{~cm}$ with well-defined margins and extension within the submucosa.

Perforation rates are around 1-2\%. A minimal technique-related gastric perforation occurred in our series (4.3\%), which was treated with 3 clips and resolved after 72 hours of clinical surveillance.

In series with smaller numbers of gastric carcinoids (10) (14) (31) (32) complications amounted to $0 \%$, but greater series showed $10 \%$ bleeding (13), as well as a miniperforation in ours (Table 3 ).

Our overall perforation rate $(4.3 \%)$ was the lowest described in the literature, and other authors report rates at $14 \%(9)$ and 5\% (23).

In summary, endoscopic treatment for digestive CTs is a valid, safe, effective alternative wherever patients are screened with EUS, as this is the most accurate technique

Table III. A literature review of gastric carcinoid tumors (GCTs) managed with polypectomy (except for the last authors, who used multiband mucosectomy (31) or bands and a cap (32))

\begin{tabular}{|c|c|c|c|c|c|}
\hline Author and year & No. & Perforation & Bleeding & $C R$ & Follow-up \\
\hline Ichikawa 2003 & $5 \mathrm{c} . / 4 \mathrm{c} .<10 \mathrm{~mm}$, with hypergastrinemia & & & $100 \%$ & $32 \mathrm{~m}$ \\
\hline Higashino 2004 & 6 c. with $8 \mathrm{G}(\mathrm{P})$ & $0(0 \%)$ & $0(0 \%)$ & $75 \%$ & $30 \mathrm{~m}$ \\
\hline Varas 2009 & $13 \mathrm{c} .(\mathrm{P}$ and $\mathrm{B})$ & $1 / 13(7.7 \%)$ & $0(0 \%)$ & $100 \%$ & $12 \mathrm{~m}$ \\
\hline Hopper 2009 (31) & 8 c. with 34 G. $7 / 8$ type I, 1/8 c. type III & $0(0 \%)$ & $0(0 \%)$ & $100 \%$ & \\
\hline Massironi 2009 (33) & Review & & & & \\
\hline \multicolumn{6}{|c|}{ Varas (2010) (35) $14 \mathrm{G}$ from a series with $40 \mathrm{CTs}$ and literature review } \\
\hline Summary & $74 \mathrm{GCT}$ & $0-7.7 \%(1.3 \%)$ & $0-10 \%$ & (1.7\%) 96\% & $21 \mathrm{~m}$ \\
\hline
\end{tabular}


for assessing tumor size and muscularis propria integrity, factors that seem to condition the potential for distant metastasis.

\section{REFERENCES}

1. Godwin JD II. Carcinoid tumors: an analysis of 2837 cases. Cancer 1975; 36: 560-9.

2. Modlin IM, Sandor A. An analysis of 8305 cases of carcinoid tumors. Cancer 1997; 79: 813-29.

3. Kulke MH, Mayer RJ. Carcinoid tumors. New Engl J Med1999; 340 : 858-68.

4. Mani S, Modlin IM, Ballantyne G, Ahlman H, West B. Carcinoids of the rectum. J Am Coll Surg 1994; 179: 231-48

5. Koura AN, Giacco GG, Curley SA, et al. Carcinoids tumors of the rectum: effect of size, histopathology, and surgical treatment on metastasis free survival. Cancer 1997; 79: 1294-8.

6. Kajiyama T, Hajiro K, Sakai M, et al. Endoscopic resection of gastrointestinal submucosal lesions: a comparison between strip biopsy and aspiration lumpectomy. Gastrointest Endosc 1996; 44: 404-10.

7. Imada-Shirakata Y, Sakai M, Kajiyama T, et al. Endoscopic resection of rectal carcinoid tumors using aspiration lumpectomy. Endoscopy 1997; 29: 34-8.

8. Higaki S, Nishiaki M, Mitani N, et al. Effectiveness of local endoscopic resection of rectal carcinoid tumors. Endoscopy 1997; 29: 171-5.

9. Yohikane H, Goto H, Niwa Y, et al. Endoscopic resection of small duodenal carcinoid tumors with strip biopsy technique. Gastrointest Endosc 1998; 47: 466-70.

10. Ichihawa J, Tanabe S, Koizumi W, et al. Endoscopic mucosal resection in the management of gastric carcinoid tumors. Endoscopy 2003; 35: 203-6.

11. Ono A, Fuji T, Saito Y, et al. Endoscopic submucosal resection of rectal carcinoid tumors with a ligation device. Gastrointest Endosc 2003; 57: 483-7.

12. Varas MJ, Espinós JC, Abad R, Bargalló D, Miquel JM. Resección endoscópica de tumores submucosos asistida por ecoendoscopia. Gastroenterol Hepatol 2003; 26 : 108.

13. Martinez-Ares D, Souto-Ruzo J, Varas Lorenzo MJ, et al. Endoscopic ultrasound-assisted endoscopic resection of carcinoid tumors of gastrointestinal tract. Rev Esp Enferm Dig 2004; 96: 847-55.

14. Higashino K, Lishi H, Narahara H, et al. Endoscopic resection with a two-channel videoendoscope for gastric carcinoid tumors. Hepatogastroenterology 2004; 51: 269-72

15. Kobayashi K, Katsumata T, Yoshizawa S, et al. Indications of endoscopic polypectomy for rectal carcinoid tumors and clinical usefulness of endoscopic ultrasonography. Dis Colon Rectum 2005; 48: 285-91.

16. Sakata H, Iwakiri R, Ootani A, et al. A pilot randomized control study to evaluate endoscopic resection using a ligation device for rec- tal carcinoid tumors. World J Gastroenterol 2006; 12: 4026-28.

17. Moon JH, Kim JH, Park CH, et al. Endoscopic submucosal resection with double ligation technique for treatment of small rectal carcinoid tumors. Endoscopy 2006; 38: 511-4.

18. Zhou P-H, Yao LQ, Xu MD, et al. Endoscopic ultrasonography and submucosal resection in the diagnosis and treatment of rectal carcinoid tumors. Chinese Med J 2007; 120: 1938-9.

19. Kim YJ, Lee SK, Cheson JH, et al. Efficacy of endoscopic resection for small rectal carcinoid: a retrospective study. Korean J Gastroenterol 2008; 51: 174-80.

20. Sohn DK, Han KS, Hong ChW, et al. Selection of cap size in endoscopic submucosal resection with cap aspiration for rectal carcinoid tumors. J Laparoendoscopic Advances Surg Techniques 2008; 18 : 815-18.

21. Mashimo Y, Matsuda T, Uraoka T, et al. Endoscopic submucosal resection with a ligation device is an effective and safe treatment for carcinoid tumors in the lower rectum. J Gastroenterol Hepatol 2008; 23: 165-6.

22. Abe T, Kakemura T, Fujinuma S, Maetani I. Successful outcomes of EMR-L with 3D-EUS for rectal carcinoids compared with historical controls. World J Gastroenterol 2008; 14: 4054-8.

23. Yamaguchi $\mathrm{N}$, Isomoto $\mathrm{H}$, Nishiyama $\mathrm{H}$, et al. Endoscopic submucosal dissection for rectal carcinoid tumors. Surg Endosc 2010; 24: 504-8.

24. Onozato Y, Kakizaki S, Lizuka H, Sohara N, Mori M, Itoh H. Endoscopic treatment of rectal carcinoid tumors. Dis colon Rectum 2010; 53: $169-76$

25. Kinoshita T, Canehira E, Omura K, Tomori T, Yamada H. Transanal endoscopic microsurgery in the treatment of rectal carcinoid tumor Surg Endosc 2007; 21: 970-4.

26. García A, Bernal JC, Morera A, Roig Vila JV. Controversias en el tratamiento quirúrgico del tumor carcinoide rectal. Rev Esp enferm Dig 2006; 98. 887-9.

27. Teleky B. The prognosis of rectal carcinoids tumours. Int J Colorrect Dis 1992; 7: 11-4.

28. Kwann MR, Goldberg JE, Bleday R. Rectal carcinoid tumors. Review of results after endoscopic and surgical therapy. Arch Surg 2008; 143: 471-5.

29. Scherübl H. local therapy of rectal carcinoids: A matter of debate Arch Surg 2009; 144: 195-6.

30. Scherübl H. Rectal carcinoids are on the rise: early detection by screening endoscopy. Endoscopy 2009; 41: 162-5.

31. Hopper AD, Bourke MJ, Hourigan LF, et al. En-bloc resection of múltiple type 1 gastric carcinoids tumors by endoscopic multi-band mucosectomy. J Gastroenterol Hepatol 2009; 24: 1516-21.

32. Muro N, Cosme A, Múgica F, Alzate LF, Bujanda L. Tratamiento de un tumor carcinoide gástrico tipo 1 mediante resección mucosa endoscópica con cabezal. Gastroenterol Hepatol 2009; 32: 533-4.

33. Massironi S, Sciola V, Spampatti MP, Peracchi M, Conte D. Gastric carcinoids: between underestimation and overtreatment. World J Gastroenterol 2009; 15: 2177-83.

34. Lin ChJ, Lin WP, Chu YY, et al. The accuracy and features of endosonography on diagnosis of gastroduodenal carcinoids tumors. Gastrointest Endosc 2009; 69 (2): S250

35. Varas MJ, Muñoz F, Espinós JC, Bardagí M. Tumores carcinoides digestivos. Rev Esp Enferm Dig 2010; 102(9); 533-7. 